\title{
Atıksu Arıtma Çamurlarının Sürdürülebilir Kullanım Alternatifleri: Öncelikli Yaklaşımlar
}

\author{
Fatma Olcay Topaç ${ }^{1 *}$, Selnur Uçaroğlu ${ }^{2}$ \\ 1* Bursa Uludağ Üniversitesi, Mühendislik Fakültesi, Çevre Mühendisliği Bölümü, Bursa, Türkiye (ORCID: 0000-0002-6364-4087), olcaytopac@uludag.edu.tr \\ ${ }^{2}$ Bursa Uludağ Üniversitesi, Mühendislik Fakültesi, Çevre Mühendisliği Bölümü, Bursa, Türkiye (ORCID: 0000-0003-4888-7934), selnur@uludag.edu.tr
}

(İlk Geliş Tarihi 5 Ağustos 2020 ve Kabul Tarihi 25 Ekim 2020)

(DOI: $10.31590 /$ ejosat.777340)

ATIF/REFERENCE: Topaç, F. O. \& Uçaroğlu, S. (2020). Atıksu Arıtma Çamurlarının Sürdürülebilir Kullanım Alternatifleri: Öncelikli Yaklaşımlar. Avrupa Bilim ve Teknoloji Dergisi, (20), 728-739.

$\ddot{O} \mathbf{z}$

Atıksu arıtma proseslerindeki mikrobiyal besin zincirinin doğal son ürünleri olan arıtma çamurları, çevre için büyük risk oluşturan atık maddeler arasında sayılmaktadırlar. Arıtma çamurlarının ikincil bir kirletici olarak birikmesi, söz konusu atıkların, işlem gördükten sonra uygun yöntemlerle bertaraf edilmesini zorunlu kılmaktadır. Çamur bertarafı için birçok yöntem bulunmakla birlikte, son yıllarda atıksu arıtma çamurlarının sürdürülebilir kullanımını hedef alan yaklaşımların hem ekonomik, hem de ekolojik açıdan ilgi odağı olduğu görülmektedir. Günümüzün öncelikli yaklaşımları çerçevesinde arıtma çamurları atık bir malzeme olarak düşünülmemekte, geri dönüşümü ya da yeniden kullanımı mümkün olan bir kaynak olarak değerlendirilmektedir. Arıtma çamurlarının yeniden kullanımı kapsamında en yaygın uygulama, stabilize edilen çamurun tarımsal arazilere gübre olarak verilmesidir. Çamurun toprak ortamına girmesiyle, bünyesinde bulunan bitki besin maddeleri ve organik maddeler topraktaki doğal döngülerine katılmakta ve tarımsal üretimde ekonomik kazanç sağlanmaktadır. Ancak son yıllarda yapılan çalışmalar, geleneksel kirleticilerin yanısıra çamurdaki mikrokirleticilerin de çevre ve insan sağlığı için bir tehdit oluşturduğuna dikkati çekmektedir. Bu çalışmaların ortaya koyduğu endişeler, tarım arazilerine yapılan çamur uygulamalarının ölçeğini ve halkın kabulünü kısıtlamaktadır. $\mathrm{Bu}$ nedenle, atıksu çamurlarının farklı amaçlarla kullanılmasına yönelik çalışmalara ağırlık verilmiştir. Bu kapsamda, susuzlaştırılmış arıtma çamurları ile çamurların yakılması sonucu elde edilen küller, çimento ve birçok yapı malzemesinin üretiminde katkı maddesi olarak kullanılabilmektedir. Diğer taraftan atıksu çamurundan enerji geri kazanımına yönelik farklı yaklaşımlara sahip pek çok teknoloji geliştirilmiş ve çok sayıda araştırma yapılmıştır. Yakma ve termal enerji geri kazanımı yoluyla elektrik üretimi, atıksu çamuru için popüler bir sürdürülebilir kullanım alternatifi olarak kabul edilmektedir. Ancak çamurun yüksek nem içeriği ve düşük ısıl değeri yüksek enerji tüketimine sebep olmakta ve ek yakıt ihtiyacı söz konusu olabilmektedir. Arıtma çamurlarından elde edilen toplam enerji miktarlarını arttırmak için, kurutma aşamasında harcanan enerjinin azaltılması ve farklı senaryolar ile net enerji dengelerinin sağlanması konularında daha fazla çalışmanın yapılmasına ihtiyaç vardır. Atıksu çamurundan proteinler, enzimler, polihidroksialkanoatlar, biyosürfaktanlar gibi katma değerli ürünlerin elde edilmesi ise, pek çok avantaj sunan ve gelecekteki çamur yönetimi alanında önemli bir yer tutabilecek yenilikçi bir yaklaşımdır. Atıksu çamurundan elde edilebilecek biyo ürünler ve değerli kaynaklar, sürdürülebilir yeşil ürün alternatifleri olarak çok farklı alanlarda kullanılabilme potansiyeline sahiptir. Arıtma çamuru tabanlı biyorafineri süreçlerinin teknolojik-ekonomik performansının daha detaylı olarak ortaya konması için kapsamlı çalışmaların yapılması gerekmektedir.

Anahtar Kelimeler: Atıksu arıtma çamuru, Sürdürülebilir kullanım, Yeniden kullanım, Geri kazanım.

\section{Sustainable Utilization Alternatives for Sewage Sludge: Priority Approaches}

\begin{abstract}
Wastewater sludges, which are the natural end products of the microbial food chain in wastewater treatment processes, are among the waste materials that pose a great risk for the environment. The accumulation of sludge as a secondary pollutant obliges those to be disposed by appropriate methods after being treated. Although there are many methods for sludge disposal, it is seen that the approaches targeting the sustainable use of wastewater sludges have been the focus of interest both economically and ecologically. Within the framework of today's priority approaches, sludge is not considered as a waste material, it is considered as a resource that can be recycled
\end{abstract}

\footnotetext{
* Sorumlu Yazar: Bursa Uludağ Üniversitesi, Mühendislik Fakültesi, Çevre Mühendisliği Bölümü, Bursa, Türkiye, ORCID: 0000-0002-6364-4087, olcaytopac@uludag.edu.tr
} 
or reused. The most common practice among reuse methods is application of stabilized sludge as fertilizer to agricultural lands. With the entry of sludge into the soil environment, the plant nutrients and organic substances in sludge participate in their natural cycles in the soil and economical gain is achieved in agricultural production. However, recent studies draw attention to the fact that micropollutants in wastewater sludge, as well as traditional pollutants, pose a threat to the environment and human health. Concerns raised by these studies limit the scale of sludge applications to agricultural lands and its public acceptance is reduced. Therefore, many studies have been conducted to use sludges for different purposes. In this context, dewatered sludges and sludge ashes can be used as additives in the production of cement as well as many construction materials. Moreover, many technologies with different approaches to energy recovery from wastewater sludge have been developed and many researches have been carried out. Electricity generation through incineration and thermal energy recovery is considered as a popular sustainable usage alternative for wastewater sludge. However, the high moisture content and low calorific value of the sludge cause high energy consumption and additional fuel demand may occur. In order to increase the total amount of energy obtained from the sludge, further work is needed to reduce the energy spent in the drying phase and to achieve net energy balances with different scenarios. Obtaining value-added products such as proteins, enzymes, polyhydroxyalkanoates, and biosurfactants from wastewater sludge is an innovative approach that offers many advantages and can take an important place in the area of sludge management in the future. Bio products and valuable resources that can be obtained from wastewater sludge have the potential to be used in many different areas as sustainable green product alternatives. Comprehensive studies are required to reveal the technological-economic performances of the sludge-based biorefinery processes.

Keywords: Wastewater sludge, Sustainable usage, Reuse, Recovery

\section{Giriş}

Endüstriyel gelişmelere, kentleşmeye ve nüfus artışına paralel olarak sürekli artan miktarlarda açığa çıkan farklı özelliklerdeki atıklar, çevre üzerindeki baskının giderek artmasına yol açmaktadır. Atıksu arıtma proseslerindeki mikrobiyal besin zincirinin doğal son ürünleri olan arıtma çamurları da, çevre için büyük risk oluşturan atık maddeler arasında sayılmaktadırlar. Arıtma çamurları, endüstriyel ya da evsel nitelikli atık suların arıtımı proseslerinde yer alan, çeşitli arıtım kademelerinde yan ürün olarak açığa çıkan yarı katı haldeki atık maddeler olarak tanımlanmakta olup, özellikleri, atıksu özellikleri ile uygulanan arıtma teknolojilerine bağlı olarak büyük oranda değişmektedir (Kumar vd., 2017). Tüm dünyada olduğu gibi ülkemizde de yüzey ve yer altı sularının korunması konusunda artan hassasiyet, atıksu arıtma tesislerinin yaygınlaşmasına yol açmış, bu da beraberinde arıtma tesislerinde oluşan çamur miktarının artışını getirmiştir. Arıtma çamurlarının bertarafı atıksu arıtma tesislerinin en pahalı işlevlerinden biridir. Tesis maliyetlerinin \%50'den fazlası çamur bertarafı için harcanmaktadır (Appels vd., 2008). Evsel ve endüstriyel atıksuların arıtımı sonucu oluşan bu büyük miktarlardaki arıtma çamurları, bitki besin maddeleri gibi faydalı elementlerin yanısıra çok farklı zararlı/zehirli maddeleri de içerebildiklerinden dolayı, özellikle global çevresel kaygılar çerçevesinde büyük ilgi odağı oluşturmaktadırlar (Lasaridi vd., 2018). Günümüzde oluşan atıksu çamurlarının \%14'ü çöp sahalarında bertaraf edilmekte, \%27'si yakılmakta, \%42'si tarımsal alanlara uygulanmakta, $\% 17 \mathrm{si}$ ise farklı sanayi sektörlerinde yeniden kullanılmaktadır (Faria vd., 2018).

Arıtma çamurlarının ikincil bir kirletici olarak birikmesi, söz konusu atıkların, arıtmanın çeşitli kademelerinde işlem gördükten sonra uygun yöntemlerle bertaraf edilmesini zorunlu kılmaktadır. Dolayısıyla çamur bertarafı çevresel perspektifin yanısıra ekonomik bakış açısıyla da atıksu arıtım sektörü ile diğer ilgili kuruluşların üzerinde önemle durduğu bir konu haline gelmiştir. Çamur bertarafı için birçok yöntem bulunmakla birlikte, son yıllarda atıksu arıtma çamurlarının sürdürülebilir kullanımını hedef alan yaklaşımların hem ekonomik hem de ekolojik açıdan ilgi odağ1 olduğu görülmektedir. Günümüzün öncelikli yaklaşımları çerçevesinde arıtma çamurları atık bir malzeme olarak düşünülmemekte, geri dönüşümü ya da yeniden kullanımı mümkün olan bir kaynak olarak değerlendirilmektedir. Son yıllarda, üretilen atık miktarını ve atık yönetiminin çevresel etkilerini azaltmak için alternatif atık yönetimi stratejilerinden faydalanılarak atık minimizasyonu ve geri dönüşüm/yeniden kullanım politikaları uygulamaya konulmuş ve benimsenen bu yaklaşım çerçevesinde çeşitli çalışmalar yürütülmüştür (Minelgaite ve Liobikiene, 2019; Pietzsch vd., 2017). Bu yaklaşıma paralel olarak dünyadaki birçok düzenleyici/uygulayıcı kurum da, atıksu çamurlarını değerli bir kaynağa dönüştürmek için çevresel açıdan sağlıklı ve ekonomik olarak uygulanabilir yolları teşvik eden önlemler almaktadır. Ülkemizde yaygın olarak tercih edilen çamur bertaraf yöntemlerinden düzenli depolamanın, özellikle Avrupa Birliği uyum sürecinde uygulamaya konulan çeşitli yönetmeliklerin etkisiyle ileriki yıllarda azalacağı ve yeniden kullanım ve geri kazanıma yönelik uygulamaların artacağı beklenmektedir. Atıksu arıtma çamurları özellikleri itibarıyla, bir malzeme ve/veya besin maddesi kaynağı olarak değerlendirilebilme potansiyeline sahiptir ve dolayısıyla endüstriyel üretim ile toprak uygulamaları kapsamında hammadde olarak kullanılabilmektedir. Diğer taraftan yakma, anaerobik çürütme, piroliz, gazlaştırma, 1slak oksidasyon gibi atıksu çamurunun faydalı bir çıktıya dönüştürülebildiği çeşitli süreçler enerji geri kazanımını da mümkün kılmaktadır. Ayrıca arıtma çamurundan katma değeri yüksek biyorafineri ürünlerin elde edilmesi de son yıllarda gündeme gelen yenilikçi yeniden kullanım alternatifleri olarak yerini bulmuştur.

$\mathrm{Bu}$ çalışmada atıksu arıtma çamurlarının sürdürülebilir kullanım alternatifleri ayrı başlıklar altında ele alınmış, avantaj ve dezavantajları irdelenmiş, yapılmış güncel çalışmalar incelenerek öncelikli yaklaşımlar değerlendirilmiş ve mevcut bilgiler ışı̆̆ında bu atık malzemelerin gelecekteki sürdürülebilir kullanımı için bir projeksiyon oluşturulmaya çalışılmıştır.

\section{Arıtma Çamurlarının Arazilerinde Kullanımı}

Arıtma çamurları, içerdikleri azot (\%2-8), fosfor (\%1-3), potasyum $(\% 0,1-0,6)$ gibi makro bitki besin maddeleri ve organik madde içerikleri itibariyle ticari gübrelere alternatif olabilecek bir gübre kaynağı olarak değerlendirilebilmektedir (Lu vd., 2012). Ayrıca arıtma çamurları, çoğu geleneksel kimyasal gübre uygulamalarıyla sağlanamayan $\mathrm{B}, \mathrm{Cu}, \mathrm{Fe}, \mathrm{Mn}$, Mo ve $\mathrm{Zn}$ gibi çok sayıda temel mikro besin elementini de içermektedir (Warman ve Termeer, 2005). Atıksu arıtımı neticesinde oluşan arıtma 
çamurları, uygun şekilde arıtıldıktan sonra tarımsal alanlarda kullanılması uygun olarak kabul edilen ve biyokatı olarak anılan bir malzemeye dönüşmektedir (Amuda vd., 2008; Lu vd., 2012). Tarım arazilerine uygulanması hedeflenen arıtma çamurlarının özellikle stabilize edilmeleri çamurun hijyenik kalitesinin sağlanması için yasal bir zorunluluk olup halk sağlığının korunması açısından büyük önem taşımaktadır (Arthurson, 2008).

Atıksu arıtma çamurlarının bitki gelişimi için ihtiyaç duyulan maddeleri sağlayabildiğini, toprağın üretkenliğini arttırdığını ve bitki büyümesini teşvik ederek hızlandırdığını ortaya koyan çok sayıda çalışma yapılmıştır. Romanos vd. (2019) tarafindan yapılan bir çalışmada Lübnan'ın Bekaa vadisinde bulunan üç farklı kentsel atıksu arıtma tesisinden temin edilen arıtma çamurlarının tarımsal alanlardaki kullanılabilme potansiyelleri değerlendirilmiştir. $\mathrm{Bu}$ kapsamda yapılan fizikokimyasal analizler, çamurun yüksek oranda mineral ve organik madde içerdiğini ve tarımsal alanlarda kullanılmasının bitki gelişimi açısından fayda sağlayabileceğini göstermiştir. Singh ve Agrawal (2010)'ın yürüttüğü bir çalışmada, pirinç (Oryza sativa L.) bitkisinin farklı oranlarda arıtma çamuru uygulamasına verdiği biyokimyasal ve fizyolojik tepkiler araştırılmış ve bitkilerdeki fotosentez ve stoma iletkenliği oranları ile klorofil ve protein içeriklerinin çamur uygulamasına bağlı olarak arttığı bilgisine ulaşılmıştır. Yaman ve Olhan (2011) tarafından yürütülen diğer bir araştırmada, buğday üretiminde atıksu arıtma çamuru kullanımının ekonomik sonuçları değerlendirilmiştir. Sonuçlara göre; arıtma çamuru kullanımı buğday verimini \%17,63 oranında arttırmıştır. Yapılan ekonomik değerlendirme, brüt kârın \%64,90 oranında arttığını, üretim maliyetinin ise \%26,01 oranında azaldığını göstermiştir. Akat ve Altunlu (2019) tarafindan yapılan bir çalışmada, arıtma çamuru uygulamasının tuzlu koşullar altındaki Limonium sinuatum (Statice) bitkisinin bitki gelişimi, verim ve çiçek kalitesi üzerindeki etkileri sera koşullarında araştırılmıştır. Elde edilen sonuçlar, tuzlu koşullarda artan arıtma çamur uygulama dozlarının, tuzun olumsuz etkilerini ortadan kaldırdığını, bitki büyümesini, verimliliği ve çiçek kalitesini olumlu yönde etkilediğini göstermiştir. Arıtma çamurlarının, kivi yetiştirilen topraklara uygulandığ 1 diğer bir çalışmada (Dede vd., 2017) topraktaki besin maddesi yarayışlılığı ile meyvenin elemental yeterliliği irdelenmiştir. Solar olarak kurutulmuş çamurların toprağa uygulanmasıyla özellikle Fe, $\mathrm{Cu}, \mathrm{Zn}, \mathrm{Mn}$ ve B konsantrasyonlarının yeterli seviyelere çıktığı tespit edilmiştir. Elde edilen veriler 1şığında, yıllık 200 ton/ha'ı aşmayacak oranlardaki stabilize çamurun yüksek $\mathrm{pH}^{\prime} \mathrm{l}_{1}$ topraklarda gerçekleştirilen kivi üretiminde güvenle kullanılabileceği sonucuna ulaşılmıştır. Bu ve benzeri çalışmalar uygun özellikler taşıyan arıtma çamurlarının toprağa uygulanmasının, bitkilerin beslenmesi açısından ticari gübrelemeye ciddi bir alternatif olabileceğine işaret etmektedir.

Diğer taraftan uygun yöntemlerle arıtılmamış ve uygun özellikler taşımayan arıtma çamuru uygulamalarına bağlı olarak, toprak ve yeraltısularının patojen, ağır metal, iz organik bileşikler ve diğer toksik kimyasallarca kirlenmesi riskini ortaya koyan çok sayıda çalışma yapılmıştır (Behbahaninia vd., 2010; Galitskaya vd., 2017; Oun vd., 2014). Özellikle son yıllarda organik mikrokirleticiler konusunda yapılan çalışmalar, atıksu çamurlarının tarımsal alanlara uygulanması ile çok sayıda mikrokirleticinin çevresel ortamlara karıştığına dikkat çekmektedir. Atıksu arıtma çamurunda sıklıkla tespit edilen organik mikrokirleticiler arasında, farmasötik maddeler, kişisel bakım ürünleri, pestisitler, hormonlar, plastikleştiriciler gibi çeşitli kimyasallar sıralanmaktadır (Kapanen vd., 2013; Semblante vd., 2015).

Özellikle farmasötik bileşikler ile ftalatların yaygın şekilde kullanılmaları ve çeşitli çevresel ortamlarda tespit edilmeleri, bu mikrokirleticilerin atıksu arıtma tesislerindeki akıbetini inceleyen çalışmalara da hız kazandırmıştır. Lamastra vd. (2018) tarafından yürütülen bir çalışmada Kuzey İtalya'da ki 35 arıtma tesisinden çıkan arıtma çamurları 2 yıl süreyle organik kirleticiler açısından izlenmiştir. Çalışma sonuçlarına göre, analiz edilen çamur örneklerinin yaklaşı $1 \%$ 'inde nonilfenoletoksilat konsantrasyonları limit değerlerin üzerinde belirlenmiştir. Analizlenen çamurların yaklaşık \%2,5'unda ise ftalat konsantrasyonlarının limit değerleri aştığı tespit edilmiştir. 45 farklı atıksu arıtma tesisinden alınan çamur örneklerinin incelendiği diğer bir çalışmada, tüm örneklerde kinolon tipi antibiyotikler tespit edilmiş ve çamurdaki konsantrasyonlarının arıtma tesisinin çalışma koşullarına ve uygulanan arıtma yöntemlerine bağlı olarak $8905 \mu \mathrm{g} / \mathrm{kg}$ kuru ağırlık seviyelerini aşabildiği vurgulanmıştır (Li vd., 2013). Benzer bir çalışmada, çamur örneklerindeki toplam östrojen konsantrasyonlarının 3,16 ila $444 \mu \mathrm{g} / \mathrm{kg}$ (kuru ağırlık) seviyeleri arasında olduğu belirlenmiştir (Sim vd., 2011). Martín vd., Alonso (2012), atıksuda tespit edilen aktif farmasötik bileşenlerin hemen hemen hepsini çamur örneklerinde de tespit etmişler ve çamurda en çok gözlenen aktif farmasötik bileşenlerin ibuprofen, salisilik asit, gemfibroliz ve kafein olduğunu belirtmişlerdir.

Bütün bu çalışmalar arıtma çamurlarının topraktaki kullanım potansiyelinin uygulama öncesi titizlikle değerlendirilmesi gerektiğini göstermektedir. Çamur içeriğindeki patojenlerin ve çeşitli makro ve mikro seviyedeki toksik kimyasalların çevre ve insan sağlığına olan etkilerinin yarattığı endişeler, bu tür uygulamaların ölçeğini ve halkın kabulünü kısıtlamaktadır.

\section{Arıtma Çamurlarının Toprak Islahı Amaçlı Kullanımı}

Arıtma çamurlarının tarım arazilerinde insan gıdası olarak kullanılan bitkilerin yetiştirilmesinde kullanılması, az gelişmiş ve gelişmekte olan ülkelerde, mevzuata uygunluğun denetimi ile uygulama sırası ve sonrasındaki izleme çalışmalarında oluşabilecek aksamalardan dolayı bir risk oluşturabilmektedir. $\mathrm{Bu}$ bakış açısıyla, stabilize edilmiş, belirgin seviyede organik madde içeren ve bitki besin maddelerince zengin olan evsel ve evsel nitelikli arıtma çamurlarının toprak özelliklerini geliştirmek veya 1slah etmek amaciyla toprak düzenleyici olarak kullanımı daha akılcı bir alternatif olabilmektedir. Tarımsal amaçla kullanılması mümkün olmayan arazilerin uygun özellikteki arıtma çamurları ile desteklenerek ıslah olması ve tarımsal değeri olan araziler haline dönüştürülmesi de mümkündür. Arıtma çamurları yüksek organik madde içeriği sayesinde metalleri bağlayabildiği ve onları daha az çözünebilir fraksiyonlara dönüştürebildiğinden, metallerle kirlenmiş toprakların iyileştirilmesinde de kullanılabilmektedir.

Arıtma çamurunun, döküm cüruflarıyla kirlenmiş bir toprağın 1slahındaki kullanımının araştırıldığı bir çalışmada, çamur uygulamasıyla toprak sızıntı suyundaki bakır, kurşun ve antimon konsantrasyonlarının, sirasiyla $250 \mu \mathrm{g} / \mathrm{L}, 80 \mu \mathrm{g} / \mathrm{L}$ ve $6 \mu \mathrm{g} / \mathrm{L}$, seviyelerinden $<20 \mu \mathrm{g} / \mathrm{L}, 40 \mu \mathrm{g} / \mathrm{L}$ ve $4 \mu \mathrm{g} / \mathrm{L}$ seviyelerine düştüğü tespit edilmiştir. $\mathrm{Bu}$ doğrultuda, arıtma çamurunun özellikle bu metallerle kirlenmiş sahaların 1slahında kullanılabileceği 
vurgulanmıştır (Navarro, 2012). Cele ve Maboeta (2016) tarafından yürütülen diğer bir çalışmada, demir cevheri maden aktivitelerinden olumsuz yönde etkilenmiş toprakların ıslahı için arıtma çamuru ilavesi ve fitostabilizasyonu içeren bir yaklaşımın değerlendirilmesi yapılmıştır. Arıtma çamuru ilavesi ile bitki uygulaması kombinasyonu, toprağın fizikokimyasal durumunu genel olarak iyileştirdiği gibi, toprak kalitesinin bir göstergesi olarak kabul edilen enzim aktivitesi seviyelerini de önemli ölçüde arttırmıştır. Eski kükürt madeni topraklarının farklı atıklarla ıslahının incelendiği bir çalışmada, yapılan uygulamaların topraklardaki katalaz, proteaz ve üreaz aktivitesini önemli derecede arttırdığı ve en büyük etkinin, arıtma çamurunun tek başına veya diğer atıklarla birlikte uygulandığı topraklarda belirlendiği tespit edilmiştir (Joniec, 2018).

Yürütülen benzer bir çalışmada, arıtma çamurunun ağır metallerle kirlenmiş toprakların fitoremediyasyonunda destekleyici materyal olarak kullanılabilirliği değerlendirilmiştir. Çalışmada kullanılan gıda endüstrisi arıtma çamurunun topraktaki humik asitleri arttırdığı, toprağın emme kapasitesi ile koruyucu tamponlama fonksiyonlarını geliştirdiği ve böylece iz metaller ile biyojenik elementlerin sızma potansiyellerini azalttığı sonucuna ulaşılmıştır. Ayrıca arıtma çamurunun gübreleme etkisi göstererek, fitoremediasyon amacıyla yetiştirilen İskoç çamı, Norveç ladini ve meşe ağaçlarının büyüme ve gelişimini desteklediği sonucuna da ulaşılmıştır (Placek vd., 2016). Metallerle kirlenmiş toprakların fitostabilizasyonunda arıtma çamurlarının rolünü ortaya koymak üzere yürütülen diğer bir araştırmada, 5 farklı çim türü (Dactylis glomerata L., Festuca arundinacea Schreb., F. rubra L., Lolium perenne L., L. Westerwoldicum) ile 5 aylık kolon çalışmaları yürütülmüştür. Arıtma çamuru uygulanan denemelerde kontrole göre daha yüksek biyokütleye ulaşılmış olup, çamurun yarattığı metal immobilizasyonu ile bitkiler tarafından metal alımında önemli bir azalma meydana gelmiştir (Kacprzak vd., 2014).

Arıtma çamurları katı atık düzenli depolama alanlarındaki örtü toprağının fizikokimyasal özelliklerini geliştirmek amacıyla da kullanılabilmektedir. Arıtma çamuru uygulamasıyla deponi sahası örtü topraklarındaki gözeneklilik, nem ve agrega oluşumu artmakta ve örtü toprakları üzerinde bitki yetiştirilebilmesi için hazır hale gelmektedir (Kim ve Owens, 2010).

\section{Arıtma Çamurlarının Toprak Islahı Amaçlı Kullanımı}

Arıtma çamurlarının içerebileceği zararlı/zehirli maddelerin besin zinciri için potansiyel kirletici olması nedeniyle toprakta kullanımı endişe oluşturmaktadır. $\mathrm{Bu}$ problem arıtma çamurlarının farklı amaçlarla kullanılmasını daha çok gündeme getirmeye başlamıştır (Lin vd., 2012). Arıtma çamurları, çimento içeriğindeki kilde de bulunan silika, alüminyum, kalsiyum, demir vb. elementleri içeren inorganik bir kısma sahiptir. Bu nedenle üretilen arıtma çamurları kurutulup yakıldıktan sonra kalan kül kısmı çimentoda katkı maddesi, toprak stabilizasyonu katkı maddesi, ince agrega veya yol dolgu malzemesi vb. olarak kullanılabilmektedir. Ayrıca, yakma sonucunda elde edilen küller diğer malzemeler ile karıştırılarak kiremit, tuğla, seramik malzemeler, kil boru gibi ürünler üretilebilmektedir (Chang vd., 2020). Son yıllarda, sadece çamur küllerinden tuğla üretiminin yapıldığ 1 yeni teknolojiler de geliştirilmiştir. Bunun yanısıra, susuzlaştırılmış çamur, yakma ve stabilizasyon sonucu elde edilen nihai üründe daha da fazla hacim azalması sağlayabilmek için eritilebilmektedir. Eritme işleminden elde edilen cüruf, yol dolgu malzemesi, beton agregası vb. olarak değerlendirilebilmekte veya karo, geçirgen blok gibi ürünlerin üretiminde ham madde olarak kullanılabilmektedir. Ayrıca, organik ve inorganik maddeler içeren susuzlaştırılmış arıtma çamurlarının da çimento bileşeni olarak kullanılabilmesi mümkündür (Valderrama vd., 2013; Zabaniotou ve Theofilou, 2008). Arıtma çamurlarının inşaat ve çimento sektöründe kullanımıyla, hacim azalması gerçekleşmekte, arıtma çamurları güvenli bir şekilde uzaklaştırılmış olmakta ve ilgili sektörlerdeki üretim maliyeti düşmektedir.

Yapılan bir çalışmada, elektrik santrali su arıtma tesisinde üretilen arıtma çamurları ve pirinç kabuklarının birlikte yakılmasıyla elde edilen küllerden, farklı yoğunluklarda ve yalıtım amaçlı kullanılabilecek iyi kalitede refraktör tuğla üretilebileceği sonucuna ulaşılmıştır (Ewais vd., 2017). González-Corrochano vd. (2017), tarafindan yürütülen bir çalışmada ise kentsel arıtma çamurları, yapay hafif agrega üretiminde kullanılmış ve uygulanan termal işlemin ağır metallerin büyük bir bölümünün tutulmasında oldukça etkili olduğu belirlenmiştir.

Areias vd. (2020) tarafindan yapılan bir çalışmada, kentsel arıtma çamurunun bina yapımında kullanılan kil tuğlalara doğrudan eklenebileceği ifade edilmiştir. Çalışmada $850^{\circ} \mathrm{C}$ ve $950^{\circ} \mathrm{C}$ ateşleme sıcaklığında ve nemli ağırlıkça \%15'e kadar kentsel arıtma çamurunun kil tuğla üretiminde kullanılabileceği ve bu şartlarda arıtma çamuru ilavesiyle, çevreye olumsuz bir etkisi olmayan standartlara uygun kil tuğlaların üretilebileceği tespit edilmiştir. Çalışmada kentsel arıtma çamuru ilavesi ile elde edilen kil tuğlaların \%16 daha uygun maliyetle üretilebileceği sonucuna varılmıştır. Dahhou vd. (2018) tarafından yürütülen diğer bir çalışmada portland çimentosu klinkeri ile içme suyu arıtma tesisi çamuru karıştırılmış ve çamur içerikli tuğla üretilebileceği belirtilmiştir. Çalışma sonuçları, arıtma çamuru karıştırılarak elde edilen portland çimentosunun ticarileşebileceğini göstermiştir. Cremades vd. (2018) tarafından yapılan bir başka çalışmada ise, kurutulmuş içme suyu arıtma tesisi çamurunun, fayans üretiminde kullanılan seramik malzemenin imalatında \%70'e kadar değişen oranlardaki kullanımı araştırılmıştır. Çalışmanın sonuçları, çamurdan düşük organik madde ve yüksek mikronize kalker içeriğine (ağırlıça $\% 14,4$ kalsiyum oksit) sahip bir toz elde edildiğini göstermiştir. $\mathrm{Bu}$ özelliklerinden dolayı arıtma çamuru tozlarının sırlı fayans üretiminde kullanılabileceği sonucuna varılmıştır. Ayrıca, çalışma kapsamında yapılan analizler, arıtma çamuru ilavesiyle elde edilen seramik malzemenin çevreye olumsuz bir etkisinin olmayacağını da göstermiştir.

\section{Arıtma Çamurlarının Enerji Kaynağı Olarak Kullanımı}

Arıtma çamurları, enerji açısından zengin bir biyokütle atığıdır. Biyodizel yakıt üretimi, anaerobik prosesler, yakma, gazifikasyon ve piroliz prosesleri gibi atıktan enerjiye dönüştüren teknolojiler ile arıtma çamurları genellikle yenilenebilir enerji kaynağı olarak kullanılmaktadırlar (Cao ve Pawlowski, 2012; Z. Liu vd., 2020; Milbrandt vd., 2018). Bu teknolojiler ile $\mathrm{H}_{2}$ ve $\mathrm{CH}_{4}$ içeren biyogaz, sıvı biyoyakıt ve katı biyoyakıt şeklinde farklı formlarda enerji ürünleri elde edilmektedir (Choi vd., 2019). Enerji elde etmenin yanı sıra, uygulanan bu teknolojiler ile kütle ve hacim azalması, patojen mikroorganizmaların giderilmesi, istenmeyen kokuların giderilmesi ve uçucu katı maddelerin stabilitesi de sağlanmaktadır (Zhang vd., 2014). Biyoyakıtlar, 
alışılmış petrol türevli yakıtlara alternatif çevreci bir yakıt olarak son yıllarda dikkat çekmektedir. Sürdürülebilir alternatif yakıtların temel özellikleri fosil yakıtlara kıyasla yenilenebilir, düşük maliyetli, verimli ve çevre açısından daha az zararlı olmalarıdır (Bora vd., 2020).

Sıvı biyoyakıtlar, gaz ve katı yakıtlara göre, ürünün kolay taşınması, ön kurutmaya ihtiyaç duyulmaması, nispeten geniş bir pazara ve yüksek satış değerine sahip olması gibi önemli avantajlara sahiptir. Bu nedenle de son yıllarda yüksek yăg içeriğine sahip kentsel arıtma çamurlarından biyodizel elde edilmesine karşı artan bir ilgi vardır (Prajitno vd., 2018). Zhang vd. (2013) tarafindan yapılan bir çalışmada atıksuyun içerdiği mikroorganizmalardan ve atıksu çamurlarından elde edilen yağlardan üretilen biyodizelin enerji verimliliği değerlendirilmiştir. $\mathrm{Bu}$ çalışma sonucunda kentsel arıtma çamurundan ekstrakte edilmiş yağdan üretilen biyodizelin, mikroorganizma kaynaklı yağ ile üretilen biyodizele göre daha avantajlı olduğu ve daha fazla enerji elde edildiği tespit edilmiştir. Choi vd. (2019) yaptıkları çalışmada, \%85 nem içeren kentsel arıtma çamurundan laboratuvar ölçekli 10 L'lik bir reaktörde ham biyodizel üretmişlerdir. Çalışma kapsamında biyodizel kalitesini arttırmak için ardışık rafinasyon prosesinin uygulanabilirliği araştırılmış ve biyodizel kalite standartları (EN 14214) esas alınarak optimal şartlar belirlenmiştir. Çalışma sonucunda rafine edilen biyodizelin kalitesinin geliştirilerek, petrol türevli yakıt kullanan araçlarda yenilenebilir yakıt ilavesi olarak kullanılabileceği ifade edilmiştir.

Çamur bertaraf yöntemleri arasında anaerobik çürütme, koku ve patojenleri gidermesi, çamuru stabilize etmesi, önemli oranda katı madde azalması sağlaması ve daha da önemlisi üretilen metan formunda yenilenebilir enerjiden dolayı, çamur yönetimi alanında avantajlı bir yöntem olarak anılmaktadır. Özellikle enerji geri kazanımı sağlaması nedeniyle, anaerobik çamur çürütme üniteleri, atıksu arıtma tesislerinin maliyetlerini düşüren önemli bir bölümü olarak kabul edilmektedirler (Zhen vd., 2017). Choi vd. (2017) yaptıkları çalışmada, atık aktif çamurun anaerobik çürütülmesinde, yağ ön ekstraksiyonunun etkilerini araştırmışlardır. Elde edilen sonuçlar, yağların ön ekstraksiyonunun çamurun çözülmesini teşvik ettiği ve yağ ön ektraksiyonu yapılmasıyla 3,65 kat daha fazla metan üretimi olduğunu ve 5 kattan daha fazla katı madde azalmasının gerçekleştiğini göstermiştir. Ultrason, yüksek basınçlı homojenizör, darbeli elektrik alanı ve termal hidroliz gibi anaerobik çürütmeden önce uygulanan çamur ön arıtma yöntemleri çamurun anaerobik biyodegredasyonunu ile biyogaz verimini önemli ölçüde arttırmakta ve nihai çamur hacmini azaltmaktadır (Carrère vd., 2010; Zhen vd., 2017). Yapılan bir çalışmada atıksu arıtma tesisinde anaerobik çürütme öncesi ön arıtma yöntemi olarak uygulanan termal hidroliz, enerji verimliliği ve ekonomi açısından değerlendirilmiştir. Termal hidroliz uygulaması, arıtma tesisinde daha düşük işletme maliyeti oluşturmuştur. Ancak termal hidrolizin etkisiyle metan üretimi azalmıştır. Yürütülen çalışma ile, uygulanan termal hidrolizin, enerji üretiminde bir artış yaratmaktan ziyade çamur bertaraf maliyetlerini önemli ölçüde azalttığı sonucuna ulaşılmıştır (Taboada-Santos vd., 2019).

Kentsel arıtma çamuru, kalorifik değerinden dolayı çimento endüstrisi için ikincil yakıt olarak kullanım potansiyeli yüksek bir alternatiftir (Valderrama vd., 2013). Fang vd. (2015) yaptıkları çalışmada çimento klinker üretiminde ikincil yakıt ve denitrifikasyon maddesi olarak kurutulmuş kentsel arıtma çamuru kullanmışlardır. Çalışmada, arıtma çamurunun $\mathrm{NO}_{\mathrm{x}}$ e-ISSN: 2148-2683 emisyonlarını \%75,82 oranında azaltan ikincil bir yakıt olduğu sonucuna varılmıştır. Alternatif yakıt olarak çamur kullanımının klinker kalitesini olumsuz etkilemediği de tespit edilmiştir. Lam vd., (2020) ise yaşam döngüsü değerlendirme analizi yaparak çamurdan enerji elde etme sistemlerini değerlendirmişlerdir. $\mathrm{Bu}$ çalışmada 16 çamurdan enerji elde eden sistem, uçucu katıların azalması, enerji geri kazanımı, enerji kullanımı, kimyasal tüketimi, üretilen çamur atıkları, oluşan çevre emisyonları temel alınarak işletme verimliliği açısından karşılaştırılmıştır. Sonuçlar, incelenen sistemlerin \%44'ünün genel teknik verimlilik açısından, \%69'unun ise saf teknik verimlilik açısından uygun olduğunu göstermiştir. Ayrıca, çalışmada yaşam döngüsü değerlendirme analizinin, düşük verime sahip sistemlerde enerji geri kazanımını arttırmak ve enerji kullanımını azaltmak gibi verimliliğe yönelik stratejiler konusunda da bilgi verdiği ifade edilmiştir.

Petrol rafineri çamurları (tank sedimentleri, yağ-su-katı seperatörleri, çözünmüş hava filtrasyon çamurları vb.) özellikle çimento firınlarında uzun yıllardır alternatif enerji kaynağı olarak kullanılmaktadır. Yapılan bir çalışmada çimento firınlarında petrol türevli enerji kaynaklarına alternatif olarak petrol rafineri çamurları ile birlikte biyojenik atıkların kullanım potansiyelleri araştırılmıştır. Biyojenik atık olarak kağıt atıkları, talaş, tahta atıkları, biyolojik çamur, düşük kalite kompost ve kuru ayrılmış kentsel atıklar kullanılmıştır. Çalışmada enerji verimliliği açısından petrol rafineri çamurlarının kompozisyonunun ve oksijen içeriğinin büyük öneme sahip olduğu, ayrıca alternatif enerji kaynağı olarak kullanımının sadece ekonomik açıdan değil, $\mathrm{NO}_{\mathrm{x}}$, civa emisyonları, $\mathrm{CO}_{2}$ emisyonları, klor bileşenleri gibi emisyonlar ve proses ekipmanlarının korozyonu açısından da çok önemli olduğu sonucuna varılmıştır (Tsiligiannis ve Tsiliyannis, 2020).

Das vd. (2020) diğer bir enerji geri kazanımı tekniği olan hidrotermal sıvılaştırma tekniği ile kentsel arıtma çamurundan hem enerji hem de nütrient (azot, fosfor vb.) geri kazanımını araştırdıkları bir çalışma yürütmüşlerdir. Yaptıkları çalışmada $\% 59$ enerji geri kazanımı, sıvı fazda azot değerinde artış, fosfor değerinde azalma, biyokömürde ise bunun tam tersi bir durum tespiti yapılmıştır. Araştırmacılar biyokömürdeki metal konsantrasyonlarında önemli bir azalma tespit etmekle beraber, uzun dönem toprak uygulamalarının izlenmesi gerekliliğini de vurgulamışlardır.

Gazifikasyon, gaz halinde bir maddenin (hava, oksijen, buhar veya hidrojen) varlığında karbonlu maddeleri, yüksek enerjili gaz ürüne termokimyasal olarak dönüştüren bir prosestir (Ahmad vd., 2016). Biyokütle gazifikasyonu, enerji üretimi için önemli bir dönüşüm yöntemi olarak kabul edilmektedir ve daha düşük kirletici emisyonları, daha yüksek enerji verimliliği ve 1sı üretimi sağlaması nedeniyle tercih edilmektedir (Gadsbøll vd., 2017). Tahta, kağıt, talaş, evsel katı atıklar ve kentsel arıtma çamuru gibi farklı tipte biyokütle yakıtları gazifikasyon prosesi ile karbon monoksit $(\mathrm{CO})$, karbon dioksit $\left(\mathrm{CO}_{2}\right)$, hidrojen $\left(\mathrm{H}_{2}\right)$, su buharı $\left(\mathrm{H}_{2} \mathrm{O}\right)$ ve metan $\left(\mathrm{CH}_{4}\right)$ içeren singaza dönüşmektedir (Liu vd., 2016; Shayana vd., 2018). Ayrıca, gazifikasyon ile üretilen singazdan geri kazanılan ısı ile yüksek nem içeriğine sahip ham kentsel arıtma çamurlarının termal olarak kurutulması da mümkün olmaktadır (Ledakowicz vd., 2019). Chen vd. (2020) tarafindan yapılan çalışmada, kentsel arıtma çamuruna sabit yataklı bir deney düzeneğinde buhar gazifikasyonu uygulanarak hidrojence zenginleştirilmiş singaz üretimi araştırılmıştır. $\mathrm{Bu}$ proses için en uygun sorbent maddenin ve optimal şartların belirlenmesi amaçlanmıştır. Çalışmanın sonucunda, hidrojence 
zengin singaz üretmek için, $\mathrm{CaO}$ sorbent maddesi ile zenginleştirilmiş gazifikasyonun kentsel arıtma çamurunun bertarafi için en uygun yöntem olduğu tespit edilmiştir. Ayol vd., (2019) tarafından yapılan çalışmada ise kentsel arıtma çamuruna aşağ 1 akışlı gazifikasyon prosesi uygulanmış ve singaz özelliklerinin yanında gazifikasyon proses atıkları olan kül ve camsı materyaller de değerlendirilmiştir. 1,2 kg gazlaştırılan kentsel arıtma çamuru için yaklaşık $1 \mathrm{kWh}$ elektrik elde edilmiştir. Çamurda bulunan ağır metallerin ağırlıklı olarak camsı materyallerin üzerinde tutulduğu belirlenmiştir. Yatırım ve işletme maliyetleri dikkate alınarak, sistemin amortisman süresinin 3,3 yıl olduğu tespit edilmiştir. Ayrıca gazifikasyon atıklarının faydalı kullanım alternatiflerine de dikkat çekilmiştir.

Kentsel arıtma çamurlarının termal kullanımında yakma ve gazifikasyon yöntemlerine alternatif olan piroliz yöntemi de üzerinde yaygın olarak çalışılan bir konu olmuştur. Yürütülen bir çalışmada kentsel arıtma çamurunun piroliz, yakma ve gazifikasyon ile termal arıtımı SWOT analizi ile irdelenmiş ve optimum termokimyasal yöntemin piroliz olduğu sonucuna ulaşılmıştır (Samolada ve Zabaniotou, 2014). Diğer metodlar ile karşılaştırıldığında piroliz kabul edilebilir seviyelerde emisyona sebep olmaktadır ve atık problemlerinin çözümünde büyük bir potansiyele sahip sıfir atık metodu olarak benimsenmiştir. Proses sonunda elde edilen biyokömür olumlu özellikleri nedeniyle toprak iyileştirme çalışmalarında kullanılabilmektedir (SyedHassan vd., 2017). Ledakowicz vd. (2019) kentsel arıtma çamuruna kurutma ve piroliz/otogazifikasyon prosesinin uygulandığı entegre bir çalışma yürütmüşlerdir. Piroliz, kireç ile $400^{\circ} \mathrm{C}$ ve $800^{\circ} \mathrm{C}$ 'de, kireçsiz $800^{\circ} \mathrm{C}^{\prime}$ de 15 ve $20 \mathrm{dk}$ süreyle uygulanmıştır. Yüksek kalorifik değere sahip pirolitik gaz ile düşük basınçlı buhar üretilerek çamurun kurutulabileceği belirtilmiştir. Piroliz/gazifikasyon prosesi ile $100 \mathrm{~kg}$ nemli çamurdan, $22 \mathrm{~kg}$ kuru çamur ve $7 \mathrm{~kg}$ biyokömür elde edildiği tespit edilmiş ve ağırlık bazında \%93 kütle azalması hesaplanmıştır. Toplam kütledeki ana kayıpların çamurun kurutulmasından kaynaklandığı belirlenmiştir. Yapılan bu çalışmada en yüksek enerjinin çamur kurutmada gerekli olduğu ve kurutma prosesinin geliştirilmesi gerektiği vurgulanmıştır. Ayrıca, proses sonunda elde edilen biyokömürün mineral içeriğinin yüksek olması, $\mathrm{P}$ ve $\mathrm{K}$ gibi biyojenik elementler içermesi, ağır metalleri bünyesinde tutup dışa vermemesi gibi olumlu özelliklerinden dolayı toprak ıslahında kullanılabileceği ifade edilmiştir. Adar vd. (2016) tarafından yapılan bir çalışmada, kentsel arıtma çamurlarının yönetimine ilişkin Türkiye'deki mevcut durum irdelenmiş ve dört farklı ölçüt göz önünde bulundurularak anaerobik çürütme, yakma, gazifikasyon, piroliz ve süperkritik su gazifikasyonu metodları SWOT-FAHP (bulanık analitik hiyerarşi prosesi) analizi ile karşılaştırılarak değerlendirilmiştir. Analiz sonucunda, dört kriterden biri olan problem çözme kriterine göre süperkritik su gazifikasyonunun, en yüksek ağırlık değerine sahip olup en avantajlı yöntem olduğu belirlenmiştir. Bu yöntemin yüksek verimlilikte arıtma sağladığı, ön arıtma gerektirmediği, daha kısa reaksiyon sürelerinde gerçekleştiği, zararlı emisyon değerleri açısından avantajlı olduğu ve daha faydalı yan ürünler ürettiği tespit edilmiştir.

\section{Arıtma Çamurlarından Elde Edilen Katma Değerli Ürünler}

Tarım arazilerine güvenle uygulanabilecek özellikteki çamur miktarının az olması ve enerji geri kazanımında çamurun yüksek nem içeriği ve düşük 1 sıl değerinin yol açtığı problemler, sürdürülebilir çamur yönetim alternatiflerinin araştırılması çabalarının da sürmesine yol açmıştır. Bu kapsamda, atıksu arıtma çamurundan çeşitli biyorafineri ürünlerin üretilmesine yönelik çalışmalar son yıllarda dikkati çekmektedir. Atıksu arıtma çamurları tipik olarak altı bileşen grubu ile karakterize edilmekte olup bunlar hücre dişı proteinler gibi toksik olmayan organik bileşikler, $\mathrm{Zn}, \mathrm{Pb}, \mathrm{Cu}$ gibi ağır metaller, toksik organik bileşikler, bakteri ve yüksek organizmalar, silikatlar, alüminatlar gibi inorganik bileşikler ve sudur (Zhang vd., 2018). Tüm bu bileşiklerin tek bir kompleks ve heterojen karışımda bulunuyor olması biyorafineri uygulamalarının temel zorluğu olmakla birlikte, atıksu çamurundan katma değeri yüksek çeşitli ürünlerin elde edilebildiğini gösteren çok sayıda çalışma yapılmıştır.

Arıtma çamurlarındaki organik maddelerin ana bileşeni lipitler, polisakkaritler ve proteinler şeklindeki kompleks bileşiklerdir ve çamurdan ekstrakte edilen proteinin çeşitli alanlarda kullanımı mümkün olabilmektedir. Yapılan pek çok çalışma arıtma çamurundan çeşitli dezentegrasyon işlemleriyle elde edilen protein ürününün, ticari olarak temin edilebilen protein yemlerine kıyasla gerekli tüm amino asitleri içerdiğini ve dolayısıyla bir hayvan yemi takviyesi olarak kullanılabileceğini göstermektedir (Hwang vd., 2008). Arıtma çamurundan geri kazanılan proteinin, çevre dostu bir gübre olarak kabul edilen amino asit ile şelatlı eser element gübresi üretmek için de kullanılabileceği bildirilmektedir (Liu vd., 2009) Ayrıca atıksu çamurundan ekstrakte edilen amino asitlerin, amino ve karboksil gruplarını içeren amfifilik moleküler yapıları nedeniyle, endüstriyel dekapaj için çevre dostu bir korozyon inhibitörü olarak kullanılabileceğini gösteren çalışmalar da mevcuttur (Gece ve Bilgiç, 2010, Go vd., 2019; Su vd., 2014). Pervaiz ve Sain (2011) ise kraft kağıt fabrikası kaynaklı atıksu çamurlarından ekstrakte ettikleri proteinin ahşap yapıştırıcı olarak kullanılabilirliğini araştırmışlar ve elde ettikleri malzemenin yapıştırma performansını soya proteini izolatı ve fenol formaldehit reçinesi ile kıyaslamışlardır. Farklı malzemelerle yapıştırılan ahşap kompozitlerin kuru kesme dayanımı ve suya olan direnç özelliklerinin incelendiği çalışma sonucunda, atıksu çamurunun çevre dostu yapıştırıcı üretimi için belirgin bir potansiyelinin olduğuna dikkat çekilmiştir.

Arıtma çamurlarından elde edilebilecek katma değerli bir diğer ürün ise enzimlerdir. Atıksu arıtma çamurunda bulunan organik maddenin çok büyük bir kısmı $0,1 \mu$ mden büyük olan ve mikroorganizma tarafından doğrudan asimile edilemeyen partiküllerden oluşmaktadır. Dolayısıyla, evsel nitelikli arıtma çamurları bünyesinde, proteaz, lipaz, glukosidaz, galaktosidaz, dehidrogenaz, katalaz, fosfataz gibi çok sayıda enzimi barındırmaktadır. Arıtma çamurundan elde edilen enzimlerin, deterjan, kozmetik, ilaç, süt ürünleri gibi çeşitli endüstrilerde kullanılabilmesi ekonomik açıdan büyük fayda sağlayabilecektir, zira bu endüstrilerdeki üretim maliyetinin önemli bir kısmını, kullanılan endüstriyel enzimler oluşturmaktadır (Kumar-Karn ve Kumar, 2019). Yapılan çalışmalar atıksu çamurlarından enzim ekstraksiyonunda, genel olarak ultrasonikasyon bazlı yöntemlerle başarılı sonuçlar elde edildiğini göstermektedir. Plattes vd. (2017) çamurdan enzim ekstraksiyonuna yönelik olarak yürüttükleri çalışmalarında bir katkı maddesi olmaksızın ultrasonik banyoda üretilen düşük güçlü ultrasesi kullanmışlar ve çamur ekstraktlarında belirlenen enzim aktivitelerinin sonikasyon zamanının artmasına bağlı olarak arttığını tespit etmişlerdir. Yu vd., (2009) tarafindan yürütülen diğer bir çalışmada 20 kHz'lik ultrases uygulamasıyla, 40kHz'lik ultrases uygulamasına ve EDTA yöntemine göre daha fazla çeşitte enzimin çamurdan 
ekstrakte edilebildiği sonucuna ulaşılmıştır. Optimum şartlarda gerçekleştirilen ultrases uygulaması ile hücrelerin parçalandığı ve hem ekstraselüler hem de küçük bir miktar intraselüler enzimin ekstrakte edilebildiği tespit edilmiştir.

Asetik asit, formik asit ve propiyonik asitler gibi kısa zincirli yağ asitleri de, çamurun anaerobik çürütülmesi veya ıslak hava oksidasyonu ve hidrotermal arıtım gibi termal işlemlerin uygulanmasıyla geri kazanılabilmektedir (H. Liu vd., 2020; Zhang vd., 2018). Uçucu yağ asitleri, pazar talebinin yüksek olduğu yapı taşı kimyasallar olarak nitelendirilmektedirler. Son zamanlarda bu uçucu asitlerin geri kazanımına yönelik çalışmalar, ilaç, gıda ve kimya endüstrilerindeki geniş kullanım alanları ve biyogaz, biyoplastik, biyodizel gibi çeşitli ürünler için değerli bir hammadde olmaları nedeniyle daha fazla dikkat çekmektedir (Atasoy vd., 2018; Begum vd., 2018; Fortela vd., 2016; Lee vd., 2014). Atık aktif çamurdan anaerobik fermentasyonla uçucu yağ asidi eldesini arttırmak için çamura ultrasonikasyon, mikrodalga, 1sıl işlem, alkali ve yüzey aktif madde ilavesi gibi alternatifleri içeren çeşitli ön işlemler uygulanmaktadır. Kakar vd. (2020) tarafindan yürütülen bir çalışmada atık aktif çamura farklı sıcaklık, alıkoyma süresi ve basınçlarda ön arıtma uygulanmış ve anaerobik asitleşme süreçleri incelenmiştir. Çalışma kapsamında en yüksek uçucu yağ asidi üretim verimi, $190^{\circ} \mathrm{C}$ 'de $10 \mathrm{dk}$ süre ile ve181 psi basınçta uygulanan hidrotermal ön arıtma ile elde edilmiştir. Ayrıca hidrotermal olarak ön işlemden geçirilmiş tüm numunelerde en bol bulunan uçucu yağ asidinin asetik asit olduğu da tespit edilmiştir. Diğer bir araştırmada ise biyolojik fosfor giderimi için sisteme eklenmesi gereken uçucu yăg asitlerinin, atıksu çamurundan geri kazanılması üzerine çalışmalar yapılarak, sıcaklık ve karıştırmanın uçucu yağ asidi geri kazanımı üzerindeki etkileri irdelenmiştir. Denemelerdeki en iyi sonuç, $24,6^{\circ} \mathrm{C}$ 'de karıştırmalı reaktörlerde elde edilmiş olup, 20 günlük toplam fermentasyon süresince açığa çıkan uçucu yağ asitlerinin \%84'ünün ilk 5 gün içinde meydana geldiği tespit edilmiştir (Yuan, 2011). Biyosürfaktan ve alkali ilavesinin uçucu yağ asidi üretimi üzerindeki etkisinin değerlendirildiği diğer bir çalışmada, saponin ilavesi ile pH 9 koşullarının birlikte kullanılması sonucunda üretilen yağ asidi miktarının, ön işlem uygulanmayan duruma göre 4,7 kat arttığı tespit edilmiştir. Ayrıca bu şartlar altında asitleşme için yeterli sübstratın sağlandığı ve uçucu yağ asitlerinin metanojenez yoluyla tüketiminin de azaldığ 1 sonucuna varılmıştır (Huang vd., 2016).

Atıksu çamurlarından elde edilebilme potansiyeli olan diğer bir ürün Bacillus thuringiensis bazlı biyopestisitlerdir. Bacillus thuringiensis, toprakta yaşayan bir bakteri olup, doğal olarak bazı otçul böcekler için ölümcül olan bir toksin üretmektedir. $\mathrm{Bu}$ toksin 1920'lerden beri böcek ilacı spreyi olarak kullanılmaktadır. Atıksu çamurundan biyopestisit üretim süreci, çamur fermentasyonu, ürün geri kazanımı ve ürün formülasyonu olmak üzere üç temel aşamadan oluşmaktadır. $\mathrm{pH}, \mathrm{C} / \mathrm{N}$ oranı, çözünmüş oksijen konsantrasyonu, köpürme, katı madde konsantrasyonu ve aşılama çamurunun tipi gibi çeşitli faktörler, biyopestisit üretim sürecini etkileyebilecek başlıca unsurlardır (Zhang vd., 2018). Syazwanee vd. (2016) tarafından yürütülen bir çalışmada atıksu çamuru ile takviye edilmiş kültür ortamlarında Bacillus thuringiensis aktivitesine dayanan biyopestisit üretim verimliliği, canlı spor sayıları temel alınarak değerlendirilmiştir. Çalışma sonuçları, yarı katı haldeki atıksu çamurunun, Bacillus thuringiensis bazlı biyopestisit üretimi için alternatif bir hammadde olma potansiyeline sahip olduğunu ancak çamurla birlikte diğer bir protein kaynağına da ihtiyaç duyulduğunu göstermiştir. Çalışma kapsamında en yüksek spor sayısı \%60 buğday kepeği ve \%40 atıksu çamuru karışımından oluşan kültür ortamında belirlenmiş olup, meyve sineğine karşı önemli düzeyde biyopestisit aktivitesi tespit edilmiştir. Zhuang vd. (2011) tarafından yürütülen benzer bir çalışmada da arıtma çamurunun Bacillus thuringiensis bazlı biyopestisit üretimi için uygun bir substrat olduğu vurgulanmış ve en yüksek canlı hücre sayısı, spor sayıs1, toksin üretimi ve entomotoksisite değeri, çamur ve buğday kepeği karışımında elde edilmiştir. Diğer bir çalışmada farklı mineral tuz içeriğine sahip belediye atıksu çamurlarından üretilen Bacillus thuringiensis süspansiyonunun, hem arazi şartlarında (yüksek UV radyasyonu) hem de depolama koşulları altında, patates yumru güvesinin larvalarına karşı çok etkili olduğu tespit edilmiştir (Saour vd., 2016).

Polihidroksialkanoatlar (PHA) çok sayıda bakteri tarafindan sentezlenen ve karbon-enerji rezervuarı olarak hücre içinde biriken bir grup biyolojik olarak parçalanabilir polyesterdir ve petrol bazlı plastiklere çevre dostu bir alternatif olmaları bakımından dikkat çekmektedirler (Akaraonye vd., 2010; Morgan-Sagastume vd., 2016). PHA'dan üretilen biyoplastiklerin fiziksel ve kimyasal özellikleri geleneksel petrol bazlı malzemelerle kıyaslanabilir niteliktedir. Ayrıca yenilenebilir kaynaklardan üretilmeleri ve tamamen biyolojik olarak parçalanabilir olmaları en önemli üstünlükleridir. Ancak, şu anda, biyoplastiklerin petrokimyasal bazlı malzemelerin yerini alması, PHA üretimi için kullanılan geleneksel yöntemlerin pahalı oluşundan dolayı kısıtlanmıştır (Gholami vd., 2016). PHA üretiminde karbon kaynağının maliyeti, toplam üretim maliyetinin \%30-50'sini bulmaktadır. Bu nedenle, PHA üretiminde düşük maliyetli bir sürecin geliştirilmesi için uygun karbon kaynaklarının kullanılması gerekmektedir (Bluemink vd., 2016). Son yıllarda yapılan pek çok çalışma atıksu çamurları gibi düşük maliyetli substratlar kullanarak işletme maliyetlerini azaltmanın mümkün olduğunu göstermektedir (Crutchik vd., 2020). Atıksu çamurları PHA üretimi için substrat olarak kullanılabildikleri gibi, PHA'ları biriktiren bir bakteri kaynağı olarak da kullanılabilmektedirler. Zira çamur bünyesinde bulunan pek çok bakteri PHA'ları biriktirebilmektedir. Yapılan çalışmalarda, atık aktif çamurdaki PHA içeriğinin 0,3 ila 22,7 mg PHA/g atık aktif çamur arasında değiştiği bildirilmiştir (Crutchik vd., 2020; Kumar vd., 2018; Salehizadeh ve Van Loosdrecht, 2004). Sonuç olarak, atıksu çamurları PHA üretimi için, hem düşük maliyetli bir karbon kaynağı hem de karışık bakteri kültürü sağlama potansiyeline sahiptir. Bu yaklaşım, PHA fiyatlarının plastik endüstrisindeki geleneksel hammaddelerle rekabet edebilecek bir aralığa düşürülmesi açısından önem arz etmektedir.

Atıksu çamurlarından elde edilebilecek diğer bir değerli metabolik yan ürün de biyosürfaktanlar ve biyoflokülanlar gibi biyopolimerlerdir. More vd. (2012) tarafından yürütülen bir çalışmada farklı katı madde içerikli atıksu çamurlarına farklı ön işlemler uygulanarak EPS (ekstraselüler polimerik bileşikler) ekstraksiyonu yapılmıştır. Çalışmada kalsiyum ile birleştirilmiş EPS'nin yüksek flokülasyon aktivitesi gösterdiği, susuzlaştırıcı özelliğinin iyi olduğu ve dolayısıyla şartlandırıcı ajan olarak kullanılabileceği ifade edilmiştir. Diğer bir çalışmada ise atık aktif çamurdan üretilen bir biyoflokülanın özellikleri incelenmiş ve materyalin, sulu çözeltilerden $\mathrm{Pb}$ (II) giderim performansı belirlenmiştir. Çalışma sonuçlarına göre elde edilen biyoflokülan ile optimum şartlarda (biyoflokülan dozu: $6 \mathrm{mg} / \mathrm{l} ; \mathrm{pH}: 6,5 ; \mathrm{CaCl}_{2}$ dozu: $70 \mathrm{mg} / \mathrm{l}$ ) sulu çözeltiden \%98,5 verimlilikte $\mathrm{Pb}$ (II) giderimi sağlanabilmiştir (Yan vd., 2020). Atık aktif çamur aynı zamanda biyoflokülan üreten mikroorganizmalar için önemli bir rezervuar olarak kabul edilmektedir. Atık aktif çamurdan, biyoflokülan 
üreten çeşitli bakteri strenlerinin (Stenotrophomonas sp., Brevisbacillus brevis, Stenotrophomonas maltophilia; Pseudomonas aeruginosa, gibi) başarıyla izole edildiği pek çok çalışmada vurgulanmıştır (Saleh vd., 2015; Singh vd., 2020; Tripathi vd., 2020).

Atıksu çamurlarındaki fosforun geri kazanılarak doğrudan tarımda kullanılabilir fosforlu minerallerin eldesi, atık çamur yönetiminde dikkati çeken diğer bir alternatiftir. Özellikle doğal fosfor rezervlerinin azalması, fosfat kayaçlarındaki fiyat artışı ve atıksu çamurlarının yüksek kirlilik seviyelerinden dolayı tarımsal alanlara doğrudan uygulanmasının zor oluşu, fosfor geri kazanımı çalışmalarına hız kazandırmıştır (Hallas vd., 2019). Atıksu çamurundan fosforun geri kazanımı için pek çok teknoloji olmakla birlikte en yaygın uygulama çamurdaki fosforlu minerallerin çökelmesine dayanan uygulamalardır. Çamur bileşimindeki fosfor, struvitler, hidroksiapatitler veya kalsiyum fosfatlar şeklinde çöktürülebilmektedir (Koga, 2019; Munir vd., 2017; Zheng vd., 2020). Diğer taraftan, son yıllarda fosfor geri kazanımına yönelik çalışmalar, atıksu çamurlarının yakılmasıyla elde edilen küllere odaklanmıştır. Zira bu küller, yakılan malzemelerin hacmindeki önemli azalmaya (\%70 ila 90) bağ l $_{1}$ olarak, çok daha fazla miktarda fosfor içermektedir (Guedes vd., 2014). Militaru vd. (2020) tarafindan yapılan bir çalışmada, $\% 4,3$ $\mathrm{P}$ içeren atıksu çamuru külündeki fosfor sülfürik asit ile ekstrakte edilmiş ve $\% 92$ oranında ekstraksiyon verimliliğine ulaşılmıştır. Struvit çöktürmesi için magnezyum sülfat heptahidrat ve amonyum klorür, magnezyum ve azot kaynağı olarak kullanılmış, ve struvit oluşumu için optimum $\mathrm{pH} 9$ olarak belirlenmiştir. Çalışma sonucunda struvit eldesi için önerilen yöntemin hem ekonomik hem de çevresel açıdan avantajlı bir yöntem olduğu vurgulanmıştır.

\section{Sonuç}

Arıtma çamurları miktarlarının çok hızlı artması nedeniyle, çamur bertarafı, tüm dünyada acil ve kaçınılmaz olarak çözülmesi gereken bir problem haline gelmiştir. Çamur bertarafi için birçok yöntem bulunmakla birlikte, son yillarda atıksu arıtma çamurlarının sürdürülebilir kullanımını hedef alan yaklaşımların hem ekonomik hem de ekolojik açıdan ilgi odağı olduğu görülmektedir.

Arıtma çamurlarının tarım arazilerine verilmesi ve/veya toprak ıslahında kullanılması yeniden kullanım alternatifleri içerisinde en yaygın olarak tercih edilen uygulama olmuştur. Şüphesiz ki, atıksu çamurunun gübre ve/veya toprak şartlandırıcı olarak kullanılmasıyla, çamur içeriğindeki organik maddeler ve faydalı elementler topraktaki doğal döngülerine katılmakta ve tarımsal üretimde ekonomik kazanç sağlanmaktadır. Ancak son yıllarda yapılan çalışmalar, geleneksel kirleticilerin yanısıra çamurdaki mikrokirleticilerin de çevre ve insan sağlı̆̆ için bir tehdit oluşturduğuna dikkati çekmekte ve bu kapsamda duyulan endişeler bu uygulamaların ölçeğini ve halkın kabulünü kısıtlamaktadır. Bu problem arıtma çamurlarının farklı amaçlarla kullanılmasını daha çok gündeme getirmektedir. Portland çimentosundaki kile benzer elementleri içeren arıtma çamurları, inşaat ve çimento sektöründe kullanılabilme potansiyeline sahiptir. Arıtma çamurlarının yakılması sonucu elde edilen küller birçok yapı malzemesi üretiminde katkı maddesi olarak fayda sağlamakta, susuzlaştırılmış arıtma çamurları da çimento bileşeni olarak kullanılabilmektedir. İnşaat ve çimento sektöründe kullanım ile arıtma çamurlarının hacmi azalmakta, bertarafı ve geri kazanımı sağlanmaktadır.
Diğer taraftan atıksu çamurundan enerji geri kazanımına yönelik farklı yaklaşımlara sahip pek çok teknolojinin geliştirildiği ve çok sayıda araştırmanın yapıldığı dikkati çekmektedir. Yakma ve termal enerji geri kazanımı yoluyla elektrik üretimi, atıksu çamuru için popüler bir sürdürülebilir kullanım alternatifi olarak kabul edilmektedir. Uygulanan bu teknolojiler ile kütle ve hacim azalmasi, patojen mikroorganizmaların giderilmesi, istenmeyen kokuların giderilmesi ve uçucu katı maddelerin stabilitesi gibi faydalar da sağlanmaktadır. Ancak, çamurun yüksek nem içeriği ve düşük ısıl değeri yüksek enerji tüketimine sebep olmakta ve ek yakıt ihtiyac1 söz konusu olabilmektedir. Yenilenebilir enerji elde edilen bu teknolojilerde arıtma çamurlarının nem içerikleri, enerji gereksinimlerini ve proses verimliliklerini belirleyen çok önemli bir parametredir. $\mathrm{Bu}$ nedenle arıtma çamurlarının susuzlaştırılması ve kurutulması, enerji geri kazanımının anahtar adımıdır. Arıtma çamurlarından elde edilen toplam enerji miktarlarını arttırmak için kurutma aşamasında harcanan enerjinin azaltılması gerekmektedir. Farklı senaryolar ile net enerji dengelerini sağlamak için daha fazla çalışmanın yapılmasına ihtiyaç vardır.

Atıksu çamurundan proteinler, enzimler, polihidroksialkanoatlar, biyosürfaktanlar gibi katma değerli ürünlerin elde edilmesi ise, pek çok avantaj sunan ve gelecekteki çamur yönetimi alanında önemli yer tutabilecek bir yaklaşımdır. Atıksu çamurundan elde edilebilecek biyo ürünler ve değerli kaynaklar sürdürülebilir yeşil ürün alternatifleri olarak çok farklı alanlarda kullanılabilme potansiyeline sahiptir. Ancak, atıksu çamuru tabanlı biyorafineri yaklaşımına yönelik çalışmaların çoğu laboratuvar ölçeğinde yapılmış olup, gelecekte her bir biyorafineri prosesinin optimize edilmesi için pilot ve tam ölçekli araştırmalarla süreçlerin teknolojik-ekonomik performansının tam olarak ortaya konması gerekmektedir.

\section{Kaynakça}

Adar, E., Karatop, B., İnce, M., \& Bilgili, M. S. (2016). Comparison of methods for sustainable energy management with sewage sludge in Turkey based on SWOT-FAHP analysis. Renewable and Sustainable Energy Reviews, 62, 429-440. http://dx.doi.org/10.1016/j.rser.2016.05.007

Ahmad, A. A., Zawawi, N. A., Kasim, F. H., Inayat, A., \& Khasri, A. (2016). Assessing the gasification performance of biomass: A review on biomass gasification process conditions, optimization and economic evaluation. Renewable and Sustainable Energy Reviews, 53, 1333-1347. http://dx.doi.org/10.1016/j.rser.2015.09.030

Akaraonye, E., Keshavarz, T., \& Roy, I. (2010). Production of polyhydroxyalkanoates: The future green materials of choice. Journal of Chemical Technology and Biotechnology, 85, 732-743. https://doi.org/10.1002/jctb.2392

Akat, H., \& Altunlu, H. (2019). The effects of sewage sludge applications on growth, yield and flower quality of limonium sinuatum (statice) under salinity conditions. Ege Üniversitesi Ziraat Fakültesi Dergisi, 56(1), 111-120. https://doi.org/ $\underline{10.20289 / \text { zfdergi.423273 }}$

Amuda, O. S., Deng, A., Alade, A. O., \& Hung Y. T. (2008). Conversion of sewage sludge to biosolids. In L.K. Wang, N.K. Shammas, \& Hung Y.T. (Eds.), Biosolids engineering and management. Handbook of environmental engineering, içinde (Bölüm 2), Humana Press.

Appels, L., Baeyens, J., Degreve, J., \& Dewil, R. (2008). Principles and potential of the anaerobic digestion of waste- 
activated sludge. Progress in Energy and Combustion Science, 34 , 755-781. https://doi.org/10.1016/j.pecs.2008.06.002

Areias, I. O. R., Vieira, C. M. F., Colorado, H. A., Delaqua, G. C. G., Monteiro, S. N., \& Azevedo, A. R. G. (2020). Could city sewage sludge be directly used into clay bricks for building construction? A comprehensive case study from Brazil. Journal of Building Engineering, 31, Article 101374. https://doi.org/10.1016/j.jobe.2020.101374

Arthurson, V. (2008). Proper sanitization of sewage sludge: A critical issue for a sustainable society. Applied and Environmental Microbiology, 74(17), 5267-5275. https://doi.org/10.1128/AEM.00438-08

Atasoy, M., Owusu-Agyemana, I., Plaza, E., \& Cetecioglu, Z. (2018). Bio-based volatile fatty acid production and recovery from waste streams: Current status and future challenges. Bioresource Technology, 268, 773-786. https://doi.org/10.1016/j.biortech.2018.07.042

Ayol, A., Yurdakos, O. T., \& Gurgen, A. (2019). Investigation of municipal sludge gasification potential: Gasification characteristics of dried sludge in a pilot-scale downdraft fixed bed gasifier. International Journal of Hydrogen Energy, 44, 17397-17410.

https://doi.org/10.1016/j.ijhydene.2019.01.014

Behbahaninia, A., Mirbagheri, S. A., \& Nouri, J. (2010). Effects of sludge from wastewater treatment plants on heavy metals transport to soils and groundwater. Iranian Journal of Environmental Health Science \& Engineering. 7. 401-406.

Begum, S., Anupoju, G. R., Sridhar, S., Bhargava, S. K., Jegatheesan, V., \& Eshtiaghi, N. (2018). Evaluation of single and two stage anaerobic digestion of landfill leachate: effect of $\mathrm{pH}$ and initial organic loading rate on volatile fatty acid (VFA) and biogas production. Bioresource Technology, 251, 364-373. https://doi.org/10.1016/j.biortech.2017.12.069

Bluemink, E., Van Nieuwenhuijzen, A. F., Wypkema, E., \& Uijterlinde, C. A. (2016). Bio-plastic (poly-hydroxyalkanoate) production from municipal sewage sludge in the Netherlands: A technology push or a demand driven process? Water Science and Technology, 74, 353-358. https://doi.org/10.2166/wst.2016.191

Bora, A. P., Gupta, D. P., \& Durbha, K. S. (2020). Sewage sludge to bio-fuel: A review on the sustainable approach of transforming sewage waste to alternative fuel. Fuel, 259, Article 116262. https://doi.org/10.1016/j.fuel.2019.116262

Cao Y., \& Pawlowski A. (2012). Sewage sludge-to-energy approaches based on anaerobic digestion and pyrolysis: Brief overview and energy efficiency assessment. Renewable and Sustainable Energy Reviews, 16(3), 1657-1665. https://doi:10.1016/j.rser.2011.12.014

Carrère, H., Dumas, C., Battimelli, A., Batstone, D. J., Delgenès, J. P., Steyer, J. P., \& Ferrer, I. (2010). Pretreatment methods to improve sludge anaerobic degradability: a review. Journal of Hazardous Materials, 183, 1-15. https://doi.org/10.1016/j.jhazmat.2010.06.129

Cele, E. N., \& Maboeta, M. (2016). Response of soil enzyme activities to synergistic effects of biosolids and plants in iron ore mine soils. International Journal of Environmental Science and Technology, 13, 2117-2126. https://doi.org/10.1007/s13762-016-1043-y

Chang, Z., Long, G., Zhou, J. L., \& Ma, C. (2020). Valorization of sewage sludge in the fabrication of construction and building materials: A review. Resources, Conservation \&
Recycling, 154, Article 104606. https://doi.org/10.1016/j.resconrec.2019.104606

Chen, S., Zhao, Z., Soomro, A., Ma, S., Wu, M., Sun, Z. \& Xiang, W. (2020). Hydrogen-rich syngas production via sorptionenhanced steam gasification of sewage sludge. Biomass and Bioenergy, 138, Article 105607. https://doi.org/10.1016/j.biombioe.2020.105607

Choi, O. K., Lee, K., Park, K. Y., Kim, J. K., \& Lee, J. W. (2017). Pre-recovery of fatty acid methyl ester (FAME) and anaerobic digestion as a biorefinery route to valorizing waste activated sludge. Renewable Energy, 108, 548-554. http://dx.doi.org/10.1016/j.renene.2017.03.004

Choi, O. K., Park, J. Y., Kim, J. K., \& Lee, J. W. (2019). Benchscale production of sewage sludge derived-biodiesel (SSD$\mathrm{BD})$ and upgrade of its quality. Renewable Energy, 141, 914921. https://doi.org/10.1016/j.renene.2019.04.030

Cremades, L. V., Cusidó, J. A., \& Arteaga, F. (2018). Recycling of sludge from drinking water treatment as ceramic material for the manufacture of tiles. Journal of Cleaner Production, 201 , 1071-1080. https://doi.org/10.1016/j.jclepro.2018.08.094

Crutchik, D., Franchi, O., Caminos, L., Jeison, D., Belmonte, M., Pedrouso, A., Val del Rio, A., Mosquera-Corral, A., \& Campos, J. L. (2020). Polyhydroxyalkanoates (PHAs) Production: A feasible economic option for the treatment of sewage sludge in municipal wastewater treatment plants. Water, 12, Article 1118. https://doi.org/10.3390/w120411187

Dahhou, M., El Moussaouiti, M., Arshad, M. A., Moustahsine, S., \& Assafi, M. (2018). Synthesis and characterization of drinking water treatment plant sludge-incorporated Portland cement. Journal of Material Cycles and Waste Management, 20, 891-901. https://doi.org/10.1007/s10163-017-0650-0

Das, P., Khan, S., AbdulQuadir, M., Thaher, M., Waqas, M., Easa, A., Attia, E. S. M., \& Al-Jabri, H. (2020). Energy recovery and nutrients recycling from municipal sewage sludge. Science of the Total Environment, 715, Article 136775. https://doi.org/10.1016/j.scitotenv.2020.136775

Dede, G., Özdemir, S., Dede, Ö. H., Altundağ, H., Dündar, M. S, \& Kizıloğlu F. T. (2017). Effects of biosolid application on soil properties and kiwi fruit nutrient composition on high$\mathrm{pH}$ soil. International Journal of Environmental Science and Technology, 14, 1451-1458. https://doi.org/10.1007/s13762017-1252-z

Ewais, E., Elsaadany, R., Ahmed, A., Shalaby, N., \& Al-Anadouli, B. (2017). Insulating refractory bricks from water treatment sludge and rice husk ash, Refractories and Industrial Ceramics, 58, 136-144. https://doi.org/10.1007/s11148-017$\underline{0071-6}$

Fang, P., Tang, Z. J., Huang, J. H., Cen, C. P., Tang, Z. X., \& Chen, $X$. B. (2015). Using sewage sludge as a denitration agent and secondary fuel in a cement plant: A case study. Fuel Processing Technology, 137, 1-7. http://dx.doi.org/10.1016/j.fuproc.2015.03.014

Faria, W. M., Figueiredo, C. C., de Coser, T. R., Vale, A. T., \& Schneider, B. G. (2018). Is sewage sludge biochar capable of replacing inorganic fertilizers for corn production? Evidence from a two-year field experiment. Archives of Agronomy and Soil Science, 64, 505-519. https://doi.org/10.1080/03650340.2017.1360488

Fortela, D. L., Hernandez, R., French, W. T., Zappi, M., Revellame, E., Holmes, W., \& Mondala, A. (2016). Extent of inhibition and utilization of volatile fatty acids as carbon sources for activated sludge microbial consortia dedicated for 
biodiesel production. Renewable Energy, 96, 11-19. https://doi.org/10.1016/j.renene.2016.04.068

Gadsbøll, R. Ø., Thomsen, J., Bang-Moller, C., Ahrenfeldt, J., \& Henriksen, U. B. (2017). Solid oxide fuel cells powered by biomass gasification for high efficiency power generation. Energy, 131, https://doi.org/10.1016/j.energy.2017.05.044

Galitskaya, I.V., Kurakalva, R. M., Krishna, K., Batrak, G. I., Eremina, O., Putilina, V. S., \& Yuganova, T. I. (2017). Assessment of soil and groundwater contamination by heavy metals and metalloids in Russian and Indian megacities. Procedia Earth and Planetary Science, 17, 674-677. https://doi.org/10.1016/j.proeps.2016.12.180

Gece, G., \& Bilgiç, S. (2010). A theoretical study on the inhibition efficiencies of some amino acids as corrosion inhibitors of nickel. Corrosion Science, 52, 3435-3443. https://doi.org/10.1016/j.corsci.2010.06.015

Gholami, A., Mohkam, M., Rasoul-Amini, S., \& Ghasemi, Y. (2016). Industrial production of polyhydroxyalkanoates by bacteria: Opportunities and challenges. Minerva Biotecnologica, 28(1), 59-74.

Go, L.C., Holmes, W., Depan, D. \& Hernandez, R. (2019). Evaluation of extracellular polymeric substances extracted from waste activated sludge as a renewable corrosion inhibitor. PeerJ, 7, Article e7193. https://doi.org/10.7717/peerj.7193

González-Corrochano, B., Alonso-Azcárate, J., Rodríguez, L., Lorenzo, A. P., Torío, M. F., Ramos, J. J. T., Corvinos, M. D., \& Muro, C. (2017). Effect heating dwell time has on the retention of heavy metals in the structure of lightweight aggregates manufactured from wastes. Environmental Technology, 39, 2511-2523. https://doi.org/10.1080/09593330.2017.1358768

Guedes, P., Couto, N., Ottosen, L. M., \& Ribeiro, A. B. (2014). Phosphorus recovery from sewage sludge ash through an electrodialytic process. Waste Management, 34, 886-892. https://doi.org/10.1016/j.wasman.2014.02.021

Hallas, J. F., Mackowiak, C. L., Wilkie, A. C., \& Harris, W. G. (2019). Struvite phosphorus recovery from aerobically digested municipal wastewater. Sustainability, 11, Article 376. https://doi.org/10.3390/su11020376

Huang, X., Mu, T., Shen, C.,Lu, L., \& Liu, J. (2016). Alkaline fermentation of waste activated sludge stimulated by saponin: volatile fatty acid production, mechanisms and pilot-scale application. Water Science and Technology, 74(12), 28602869. https://doi.org/10.2166/wst.2016.459

Hwang, J., Zhang, L., Seo, S., Lee, Y. W., \& Jahng, D. (2008). Protein recovery from excess sludge for its use as animal feed. Bioresource Technology, 99(18), 8949-8954. https://doi.org/10.1016/j.biortech.2008.05.001

Joniec, J. (2018). Enzymatic activity as an indicator of regeneration processes in degraded soil reclaimed with various types of waste. International Journal of Environmental Science and Technology, 15, 2241-2252. https://doi.org/10.1007/s13762-017-1602-x

Kacprzak, M., Grobelak, A., Grosser, A., \& Prasad, M. N. V. (2014) Efficacy of biosolids in assisted phytostabilization of metalliferous acidic sandy soils with five grass species. International Journal of Phytoremediation, 16(6), 593-60. https://doi.org/ 10.1080/15226514.2013.798625

Kakar, F., Koupaie, E. H., Razavi, A. S., Hafez, H., \& Elbeshbishy, E. (2020). Effect of hydrothermal pretreatment on volatile fatty acids production from thickened waste activated sludge. Bioenergy Research, 13, 591-604. https://doi.org/10.1007/s12155-019-10056-Z

Kapanen, A., Vikman, M., Rajasärkkä, J., Virta, M., \& Itävaara, M. (2013). Biotests for environmental quality assessment of composted sewage sludge. Waste Management, 33, 14511460. https://doi.org/10.1016/j.wasman.2013.02.022

Kim, K. R., \& Owens, G. (2010). Potential for enhanced phytoremediation of landfills using biosolids - a review. Journal of Environmental Management, 91, 791-797. https://doi.org/10.1016/j.jenvman.2009.10.017

Koga, D. (2019). Struvite recovery from digested sewage sludge. In: H. Ohtake, \& S. Tsuneda (Eds.), Phosphorus recovery and recycling (pp. 255-264). Springer.

Kumar, V., Chopra, A. K., \& Kumar, A. (2017). A review on sewage sludge (Biosolids) a resource for sustainable agriculture. Archives of Agriculture and Environmental Science, 2(4), $340-347$ https://doi.org/10.26832/24566632.2017.020417

Kumar, M., Ghosh, P., Khosla, K., \& Thakur, I. S. (2018). Recovery of polyhydroxyalkanoates from municipal secondary wastewater sludges. Bioresource Technology, 255, 111-115. https://doi.org/10.1016/j.biortech.2018.01.031

Kumar-Karn, S., \& Kumar, A. (2019) Sludge: next paradigm for enzyme extraction and energy generation. Preparative Biochemistry and Biotechnology, 49(2), 105-116. https://doi.org/10.1080/10826068.2019.1566146

Lam, C. M., Hsu, S. C., Alvarado, V., \& Li, W. M. (2020). Integrated life-cycle data envelopment analysis for technoenvironmental performance evaluation on sludge to energy systems. Applied Energy, 266, Article 114867. https://doi.org/10.1016/j.apenergy.2020.114867

Lamastra, L., Suciu, N. A., \& Trevisan, M. (2018). Sewage sludge for sustainable agriculture: Contaminants' contents and potential use as fertilizer. Chemical and Biological Technologies in Agriculture 5, Article 10. https://doi.org/10.1186/s40538-018-0122-3

Lasaridi, K. E., Manios, T., Stamatiadis, S., Chroni, C., \& Kyriacou, A. (2018). The evaluation of hazards to man and the environment during the composting of sewage sludge. Sustainability, $10, \quad$ Article 2618. https://doi.org/10.3390/su10082618

Ledakowicz, S., Stolarek, P., Malinowski, A., \& Lepez, O. (2019). Thermochemical treatment of sewage sludge by integration of drying and pyrolysis/autogasification. Renewable and Sustainable Energy Reviews, 104, 319-327. https://doi.org/10.1016/j.rser.2019.01.018

Lee, W. S., Chua, A. S. M., Yeoh, H. K., \& Ngoh, G. C. (2014) A review of the production and applications of waste-derived volatile fatty acids. Chemical Engineering Journal, 235, 8399. https://doi.org/10.1016/j.cej.2013.09.002

Li, W., Shi, Y., Gao, L., Liu, J., \& Cai, Y. (2013). Occurrence, distribution and potential affecting factors of antibiotics in sewage sludge of wastewater treatment plants in China. Science of the Total Environment, 445-446, 306-313. https://doi.org/10.1016/j.scitotenv.2012.12.050

Lin, Y. M., Zhou, S. Q., Li, F. Z., \& Lin, Y. X. (2012). Utilization of municipal sewage sludge as additives for the production of eco-cement, Journal of Hazardous Materials, 213-214, 457465. https://doi.org/10.1016/j.jhazmat.2012.02.020

Liu, Y., Kong, S., Li, Y., \& Zeng, H. (2009). Novel technology for sewage sludge utilization: Preparation of amino acids chelated trace elements (AACTE) fertilizer. Journal of 
Hazardous $\quad$ Materials, 171, 1159-1167. https://doi.org/10.1016/j.jhazmat.2009.06.123

Liu, Z., Norbeck, J. M., Raju, A.S.K., Kim, S., \& Park, C.S. (2016). Synthetic natural gas production by sorption enhanced steam hydrogasification based processes for improving $\mathrm{CH} 4$ yield and mitigating $\mathrm{CO} 2$ emissions. Energy Conversion and Management, 126, 256-265. http://dx.doi.org/10.1016/j.enconman.2016.08.008

Liu, H., Li, Y., Fu, B., Guo, H., Zhang, J., \& Liu, H. (2020) Chapter 8 - Recovery of volatile fatty acids from sewage sludge through anaerobic fermentation, In S. Varjani, A. Pandey, E. Gnansounou, S.K. Khanal, \& S. Raveendran (Eds.), Current developments in biotechnology and bioengineering içinde (pp. 151-177) Elsevier. https://doi.org/10.1016/B978-0-444-64321-6.00008-2

Liu, Z., Mayer, B. K., Venkiteshwaran, K., Seyedi, S., Raju, A. S. K., Zitomer, D., \& McNamara, P. J. (2020). The state of technologies and research for energy recovery from municipal wastewater sludge and biosolids. Current Opinion in Environmental Science \& Health, 14, 31-36. https://doi.org/10.1016/j.coesh.2019.12.004

Lu, Q., He, Z. L., \& Stoffella, P. J. (2012). Land application of biosolids in the USA: A review. Applied and Environmental Soil Science, Article 201462. https://doi.org/10.1155/2012/201462

Martín, J., Camacho-Muñoz, D., Santos, J. L., Aparicio, I., \& Alonso, E. (2012). Occurrence of pharmaceutical compounds in wastewater and sludge from wastewater treatment plants: removal and ecotoxicological impact of wastewater discharges and sludge disposal. Journal of Hazardous Materials, 239-240, 40-47. https://doi.org/10.1016/j.jhazmat.2012.04.068

Milbrandt, A., Seiple T., Heimiller, D., Skaggs, R., \& Coleman, A. (2018). Wet waste-to-energy resources in the United States. Resources, Conservation \& Recycling, 137, 32-47. https://doi. org/10.1016/j.resconrec.2018.05.023

Militaru, B. A., Pode, R. , Lupa, L., \& Manea, F. (2020). Struvite precipitation from sewage sludge ash. Environmental Engineering and Management Journal,19(2), 303-310.

Minelgaite, A., \& Liobikiene, G. (2019). Waste problem in European Union and its influence on waste management behaviours. Science of The Total Environment, 667, 86-93. https://doi.org/10.1016/j.scitotenv.2019.02.313

More, T., Yan, S., Hoang, N., Tyagi, R., \& Surampalli, R. (2012). Bacterial polymer production using pre-treated sludge as raw material and its flocculation and dewatering potential. Bioresource Technology, 121, 425-431. https://doi.org/10.1016/j.biortech.2012.06.075

Morgan-Sagastume, F., Heimersson, S., Laera, G., Werker, A., \& Svanström, M. (2016). Techno-environmental assessment of integrating polyhydroxyalkanoate (PHA) production with services of municipal wastewater treatment. Journal of Cleaner Production, 137, 1368-1381. https://doi.org/10.1016/j.jclepro.2016.08.008

Munir, M.T., Li, B., Boiarkina, I., Baroutian, S., Yu, W., \& Young, B.R. (2017). Phosphate recovery from hydrothermally treated sewage sludge using struvite precipitation. Bioresource Technology, 239, 171-179. https://doi.org/10.1016/j.biortech.2017.04.129

Navarro, A. (2012) Effect of sludge amendment on remediation of metal contaminated soils. Minerals, 2, 473-492. https://doi.org/10.3390/min2040473
Oun, A., Kumar, A., Harrigan, T., Angelakis, A., \& Xagoraraki, I. (2014). Effects of biosolids and manure application on microbial water quality in rural areas in the US. Water, 6, 3701-3723. https://doi.org/10.3390/w6123701\#sthash.H76q6NWK.dpuf

Pervaiz, M., \& Sain, M. (2011). Protein adhesive from sludges. BioResources, 6(2), 961-970.

Pietzsch, N., Ribeiro, J.L.D., \& De Medeiros, J.F. (2017) Benefits, challenges and critical factors of success for Zero Waste: A systematic literature review. Waste Management, 67, 324353. https://doi.org/10.1016/j.wasman.2017.05.004

Placek, A., Grobelak, A., \& Kacprzak, M. (2016). Improving the phytoremediation of heavy metals contaminated soil by use of sewage sludges. International Journal of Phytoremediation, $\quad 18 \quad$ (6), 605-618. https://doi.org/10.1080/15226514.2015.1086308

Plattes, M., Koehler, C., \& Gallé, T. (2017). Purely ultrasonic enzyme extraction from activated sludge in an ultrasonic cleaning bath. MethodsX, 4, 214-217. https://doi.org/10.1016/j.mex.2017.07.003

Prajitno, H., Park, J., Ryu, C., Park, H. Y., Lim, H. S., \& Kim, J. (2018). Effects of solvent participation and controlled product separation on biomass liquefaction: a case study of sewage sludge. Applied Energy, 218, 402-416. https://doi.org/10.1016/j.apenergy.2018.03.008

Romanos, D., Nemer, N., Khairallah, Y., \& Abi Saab, M.T. (2019). Assessing the quality of sewage sludge as an agricultural soil amendment in Mediterranean habitats. International Journal of Recycling of Organic Waste in Agriculture, 8, 377-38. https://doi.org/10.1007/s40093-01900310-X

Saleh, F., Azizi, H., Kheirandish, F., Bari, M., \& Azizi, M. (2015). Media optimization for biosurfactant production by Pseudomonas aeruginosa isolated from activated sludge reservoirs. Petroleum Science and Technology, 33(1), 1-7. https://doi.org/ 10.1080/10916466.2014.942426

Salehizadeh, H., \& Van Loosdrecht, M.C.M. (2004). Production of polyhydroxyalkanoates by mixed culture: Recent trends and biotechnological importance. Biotechnology Advences, 22,

https://doi.org/10.1016/j.biotechadv.2003.09.003

Samolada, M. C., \& Zabaniotou, A. A. (2014). Comparative assessment of municipal sewage sludge incineration, gasification and pyrolysis for a sustainable sludge-to-energy management in Greece. Waste Management, 34, 411-420. http://dx.doi.org/10.1016/j.wasman.2013.11.003

Saour, G., Al-Mariri, A., \& Hashem, A. (2016). Evaluation of Bacillus thuringiensis cultured in wastewater sludges against the potato tuber moth (Lepidoptera: Gelechiidae). Entomologia Generalis, $36 \quad$ (2), 149-161. https://doi.org/10.1127/entomologia/2016/0212

Semblante, G. U., Hai, F. I., Huang, X., Ball, A. S., Price, W. E., \& Nghiem, L. D. (2015). Trace organic contaminants in biosolids: Impact of conventional wastewater and sludge processing technologies and emerging alternatives. Journal of Hazardous Materials, 300, 1-17. https://doi.org/10.1016/j.jhazmat.2015.06.037

Shayana, E., Zareb, V., \& Mirzaeea, I. (2018). Hydrogen production from biomass gasification; a theoretical comparison of using different gasification agents. Energy Conversion and Management, 159, 30-41. https://doi.org/10.1016/j.enconman.2017.12.096 
Sim, W. J., Lee, J. W., Shin, S. K., Song, K. B., \& Oh, J. E. (2011). Assessment of fates of estrogens in wastewater and sludge from various types of wastewater treatment plants. Chemosphere, $82, \quad 1448-1453$. https://doi.org/10.1016/j.chemosphere.2010.11.045

Singh, R. P., \& Agrawal, M. (2010). Biochemical and physiological responses of rice (Oryza sativa L.) grown on different sewage sludge amendments rates. Bulletin of Environmental Contamination and Toxicology, 84(5), 606612. https://doi.org/10.1007/s00128-010-0007-z

Singh, R., Kumar-Singh, S., \& Rathore, D. (2020). Analysis of biosurfactants produced by bacteria growing on textile sludge and their toxicity evaluation for environmental application. Journal of Dispersion Science and Technology, 41(4), 510522. https://doi.org/ 10.1080/01932691.2019.1592686

Su, W., Tang, B., Fu, F., Huang, S., Zhao, S., Bin, L., Ding, J., \& Chen, C. (2014). A new insight into resource recovery of excess sewage sludge: Feasibility of extracting mixed amino acids as an environment-friendly corrosion inhibitor for industrial pickling. Journal of Hazardous Materials, 279, 3845. https://doi.org/10.1016/j.jhazmat.2014.06.053

Syazwanee, M., Noormasshela, U. A., Azwady, A. A., Rusea, G., \& Muskhazli, M. (2016). Bacillus thuringiensis entomotoxicity activity in wastewater sludge-culture medium towards Bactrocera dorsalis and their histopathological assessment. Sains Malaysiana, 45(4), 589-594.

Syed-Hassan, S. S. A., Wang, Y., Hu S., Su, S., \& Xiang J. (2017). Thermochemical processing of sewage sludge to energy and fuel: fundamentals, challenges and considerations. Renewable and Sustainable Energy Reviews, 80, 888-913. http://dx.doi.org/10.1016/j.rser.2017.05.262

Taboada-Santos A., Lema, J. M., \& Carballa, M. (2019). Energetic and economic assessment of sludge thermal hydrolysis in novel wastewater treatment plant configurations. Waste Management, 92, 30-38. https://doi.org/10.1016/j.wasman.2019.05.003

Tripathi, V., Gaur, V. K., Dhiman, N., Gautam, K., \& Manickam, N. (2020). Characterization and properties of the biosurfactant produced by PAH-degrading bacteria isolated from contaminated oily sludge environment. Environmental Science and Pollution Research, 27(22), 27268-27278. https://doi.org/10.1007/s11356-019-05591-3

Tsiligiannis, A., \& Tsiliyannis, C. (2020). Oil refinery sludge and renewable fuel blends as energy sources for the cement industry. Renewable Energy, 157, 55-70. https://doi.org/10.1016/j.renene.2020.03.129

Valderrama, C., Granados, R., \& Cortina, J. L. (2013). Stabilisation of dewatered domestic sewage sludge by lime addition as raw material for the cement industry: Understanding process and reactor performance. Chemical Engineering Journal, 232, 458-467. http://dx.doi.org/10.1016/j.cej.2013.07.104

Warman, P. R. \& Termeer, W. C. (2005). Evaluation of sewage sludge, septic waste and sludge compost applications to corn and forage: $\mathrm{Ca}, \mathrm{Mg}, \mathrm{S}, \mathrm{Fe}, \mathrm{Mn}, \mathrm{Cu}, \mathrm{Zn}$ and $\mathrm{B}$ content of crops and soils. Bioresource Technology, 96(9), 1029-1038. https://doi.org/10.1016/j.biortech.2004.09.014

Yaman, K., \& Olhan, E. (2011). Impact of sewage sludge application on yield, physical input and costs of wheat. Journal of Agricultural Sciences-Tarım Bilimleri Dergisi, 17, 157-166

Yan, Z., Peng, L., Deng, M., \& Lin, J. (2020). Production of a bioflocculant by using activated sludge and its application in $\mathrm{Pb}$ (II) removal from aqueous solution. Open Chemistry, 18(1), 333-338. https://doi.org/10.1515/chem-2020-0024

Yu, G., He, P., Shao, L., \& Zhu, Y. (2009). Enzyme extraction by ultrasound from sludge flocs. Journal of Environmental Sciences, 21(2), 204-210. https://doi.org/10.1016/S10010742(08)62252-4

Yuan, Q., Sparling, R., \& Oleszkiewicz, J.A. (2011) VFA generation from waste activated sludge: Effect of temperature and mixing. Chemosphere, 82, 603-607. https://doi.org/10.1016/j.chemosphere.2010.10.084

Zabaniotou, A., \& Theofilou, C. (2008). Green energy at cement kiln in Cyprus - Use of sewage sludge as a conventional fuel substitute. Renew. Sustain. Energy Rev., 12, 531-541. https://doi.org/10.1016/j.rser.2006.07.017

Zhang, X., Yan, S., Tyagi, R. D., \& Surampalli, R. Y. (2013). Energy balance and greenhouse gas emissions of biodiesel production from oil derived from wastewater and wastewater sludge. Renewable Energy, 55, 392-403. http://dx.doi.org/10.1016/j.renene.2012.12.046

Zhang, L., Xu, C. C., Champagne, P., \& Mabee, W. (2014). Overview of current biological and thermochemical treatment Technologies for sustainable sludge management. Waste Management\&Research, 32(7), 586-600. http://dx.doi.org/10.1177/0734242X14538303

Zhang, W., Alvarez-Gaitan, J. P., Dastyar, W., Saint, C. P., Zhao, M., \& Short, M. D. (2018). Value-added products derived from waste activated sludge: A biorefinery perspective. Water, 10, 545. https://doi.org/10.3390/w10050545

Zhen, G., Lu, X., Kato, H., Zhao, Y., \& Li, Y. Y. (2017). Overview of pretreatment strategies for enhancing sewage sludge disintegration and subsequent anaerobic digestion: current advances, full-scale application and future perspectives. Renewable and Sustainable Energy Reviews, 69, 559-577. http://dx.doi.org/10.1016/j.rser.2016.11.187

Zheng, X., Ye, Y., Jiang, Z., Ying, Z., Ji, S., Chen, W., Wang, B., \& Dou, B. (2020). Enhanced transformation of phosphorus (P) in sewage sludge to hydroxyapatite via hydrothermal carbonization and calcium-based additive. Science of The Total Environment, 738, Article 139786. https://doi.org/10.1016/j.scitotenv.2020.139786

Zhuang, L., Zhou, S., Wang, Y., Liu, Z., \& Xu, R. (2011). Costeffective production of Bacillus thuringiensis biopesticides by solid-state fermentation using wastewater sludge: Effects of heavy metals. Bioresource Technology, 102, 4820-4826. https://doi.org/10.1016/j.biortech.2010.12.098 